\title{
Kasus urolitiasis pada kucing persia betina
}

\author{
Arief P. Mihardi ${ }^{1,2, *}$, Putra R. Hidayat ${ }^{3}$, Aisyah Nurlatifah ${ }^{3}$, Ni Putu Wirananda Ayuning Permata ${ }^{3}$, \\ Tri Ayu Kristianty ${ }^{4}$ \\ ${ }^{1}$ Departemen Klinik Reproduksi dan Patologi, Fakultas Kedokteran Hewan, Institut Pertanian Bogor, Bogor. \\ ${ }^{2}$ Dokter Hewan Praktisi, Maximus Pet Care, Bogor. \\ ${ }^{3}$ Program Pendidikan Profesi Dokter Hewan, Fakultas Kedokteran Hewan, Institut Pertanian Bogor, Bogor. \\ ${ }^{4}$ Dokter Hewan Praktisi, Klinik Hewan My Vets, Jakarta Selatan
}

\begin{abstract}
ABSTRAK: Urolithiasis merupakan gangguan pada hewan jantan maupun betina berupa adanya kristal atau batuan pada traktus urinarius seperti vesika urinaria. Tulisan ini melaporkan kasus urolitiasis pada seekor kucing ras persia bernama Suki berjenis kelamin betina dibawa pemiliknya datang ke klinik dengan keluhan sulit urinasi dan ada respon sakit saat urinasi. Kucing tersebut sebelumnya pernah datang ke klinik dengan gejala stranguria dan hematuria. Vesika urinaria kucing tidak tegang namun ditemukan hematuria saat dilakukan pemeriksaan fisik. Pemeriksaan penunjang dilakukan dengan radiografi dan ditemukan masa radioopaque di dalam vesika urinaria. Kucing didiagnosa urolitiasis dan diterapi dengan cystotomi untuk mengambil masa di dalam vesika urinaria. Pengobatan pasca-cystotomi diberikan obat antiinflamasi, antinyeri dan antibiotik. Kucing tersebut menunjukkan persembuhan yang lebih baik pasca-cystotomi.

Kata kunci:

cystotomi, hematuria, kucing betina, stranguria, urolitiasis
\end{abstract}

\section{- PENDAHULUAN}

Urolitiasis merupakan gangguan pada saluran urinari akibat adanya batu/kalkuli/kristal-kristal. Kalkuli tersebut dapat menimbulkan sumbatan bahkan perlukaan pada saluran urinari (Hesse \& Heiger 2009). Menurut Grauer (2015), manifestasi klinis pada kejadian urolitiasis bersifat nonspesifik dan sangat bervariasi tergantung dari besarnya, jumlah dan lokasi kalkuli. Urolitiasis pada umumnya diikuti hematuria, disuria, serta stanguria (Gerber et al. 2005).

Menurut Osborne et al. (2009), hasil observasi sejak tahun 1981 hingga 2007 kejadian urolotiasis pada kucing mencapai 94.778 kasus. Jenis urolit yang sering didapat yaitu struvite dan kalsium oksalat. Persentase kedua jenis urolit ini menunjukankan perubahan tiap periode. Menurut Hesse \& Heiger (2009), persentase tipe urolit yang sering ditemukan pada kucing yaitu struvit 33\%, kalsium oksalat 9\% dan asam urat 6\%. Menurut Kojrys et al. (2017), pada 385 kucing yang mengalami gangguan pada saluran urinarius bagian bawah ditemukan 13\% menunjukkan adanya urolit. Sejalan dengan hasil studi Mihardi et al. (2018), dari 13 sampel urin yang diperoleh dari kucing yang mengalami gangguan saluran urinarius bagian bawah terdapat $76.92 \%$ ditemukan kristal pada sampel urin tersebut. Sampel yang positif terdapat kristal menunjukkan $80 \%$ merupakan jenis struvit dan $20 \%$ jenis mix (struvit dan kalsium oksalat). Tulisan ini bertujuan untuk mengulas kasus urolitiasis serta tindakan terapi pada kucing, khususnya pada kucing betina.

\section{KASUS}

Sinyalemen: Kucing dengan ras persia bernama Suki dengan jenis kelamin betina dan rambut berwarna putih abu-abu (Gambar 1). Anamnesa: Pemilik membawa kucing ke klinik My Vets dengan keluhan sulit urinasi dan menunjukkan respon sakit saat miksi. Sebelumnya pernah dibawa ke klinik dengan keluhan stranguria dan hematuria. Gejala klinis: Suhu tubuh $38.3^{\circ} \mathrm{C}$, frekuensi nafas 36 $\mathrm{kali} /$ menit, frekuensi jantung $124 \mathrm{kali} /$ menit, vesika urinaria tidak tegang dan terdapat darah pada urin (hematuria). Pemeriksaan penunjang: Pemeriksaan radiografi ditemukan masa radioopaque pada bagian vesika urinaria (Gambar 2). Diagnosa: Urolitiasis. Prognosa: Fausta.

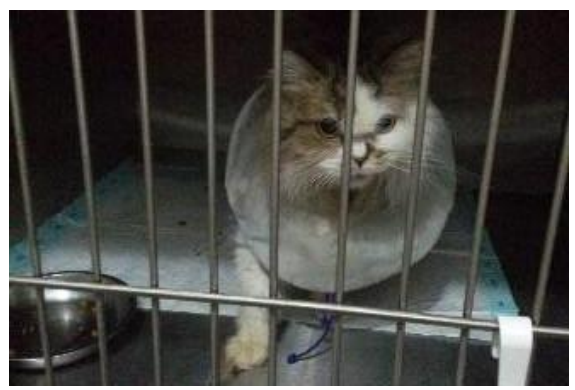

Gambar 1 Kucing Suki yang mengalami urolitiasis.

Diterima: 02-02-2019 | Direvisi: 26-02-2019 | Disetujui: 28-02-2019

(C) 2019 CC-BY-SA. Ini adalah artikel Open Access yang didistribusikan berdasarkan ketentuan dari Creative Commons Attribution ShareAlike 4.0 International License (https://creativecommons.org/licenses/by-sa/4.0/). 


\section{- HASIL DAN PEMBAHASAN}

Urolit merupakan penyakit akibat nutrisi pada hewan karnivor domestik (Tion et al. 2015). Menurut Hesse \& Heiger (2009), kristal urolit dapat menimbulkan sumbatan bahkan perlukaan pada saluran urinari. Urolitiasis dapat diartikan juga sebagai pembentukan sedimen dalam saluran urinari yang terdiri dari bahan kristaloid urin yang sulit larut atau adanya agregasi antara bahan kristal dan matriks pada saluran urinari ketika urin menjadi jenuh (Ulrich et al. 1996). Prevalensi batu pada saluran kemih sering terjadi pada kucing yang kurang asupan air dan tingginya mineral kalsium. Selain itu hewan yang diet tinggi purin, oksalat, dan kalsium mempermudah terjadinya batu di saluran kemih (Bartges \& Kirk 2006).

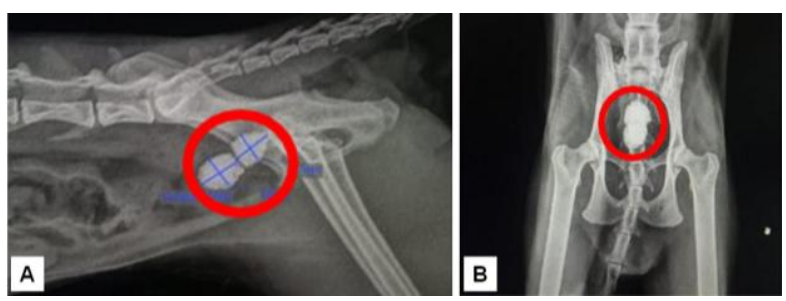

Gambar 2 Radiografi kucing ras Persia bernama Suki tampak masa radioopaque pada bagian abdomen (lingkaran merah). (A) posisi lateral recumbency, (B) posisi ventrodorsal.

Terdapat beberapa penjelasan dan teori tentang terbentuknya urolit. Ada tiga teori yang menjelaskan terbentuknya urolit pada saluran urinari yaitu endapan kritalisasi, pembentukan inti matriks, dan penghambat faktor kristalisasi. Endapan kristalisasi terjadi akibat kejenuhan yang tinggi (supersaturation) antara urin dan kristaloid kemudian berkembang menjadi kalkuli. Pembentukan inti matriks (komponen organik non kristal dari kalkuli seperti albumin dan globulin) yaitu substansi abnormal dari urin menjadi penyebab awal terjadinya pembentukan kalkuli. Teori penghambat kristalisasi menyatakan bahwa faktor penghambat pembentukan kalkuli tidak tersedia (Hesse \& Heiger 2009). Menurut Bartes \& Kirk (2006), terbentuknya batu pada saluran kemih dapat disebabkan oleh 3 faktor, yaitu konsentrasi kristaloid yang tinggi dalam urin, lesi pada dinding saluran urinarius atau perubahan fisikokimia dalam urin hingga terbentuknya kristal, dan stastis air kemih. Pembentukan batu dapat terjadi karena urin yang jenuh dengan garam-garam pembentuk batu atau urin kekurangan faktor penghambat pembentukan batu. Kotoran dan debris dalam urin juga akan mengendap sehingga mengkristal dan membentuk batu-batu dalam saluran urinarius.

Gejala klinis yang ditemukan pada kucing Persia bernama Suki yaitu menunjukkan rasa nyeri saat urinasi dan adanya darah saat urinasi. Menurut Brown (2018), gejala klinis yang sering nampak pada kasus urolitiasis yaitu adanya hematuria, disuria atau bahkan adanya obstruksi pada uretra. Pemeriksaan radiografi dapat membantu dalam meneguhkan diagnosa, karena hanya $10 \%$ kasus urolitiasis pada kucing dapat dideteksi melalui palpasi profundal pada regio abdominal. Hal tersebut sejalan dengan kasus kucing Suki saat dilakukan palpasi abdominal tidak ditemukan adanya masa dalam vesika urinaria.

Tindakan yang dilakukan untuk menangani kasus kucing Suki yaitu dengan cystotomi untuk mengambil masa (kalkuli) dalam vesika urinaria. Pengobatan pascacystotomi pada kucing Suki yaitu diberikan obat antibiotik, anti inflamasi dan anti nyeri selama satu minggu. Kucing Suki menunjukkan tingkat persembuhan yang lebih baik pasca-cystotomi hingga dijemput untuk pulang oleh pemilik.

\section{- SIMPULAN}

Urolitiasis pada kucing dengan gejala berupa rasa nyeri saat urinasi disertai hematuria. Peneguhan diagnosa radiografi menunjukkan masa radioopaque pada vesika urinaria. Terapi bedah dan obat memberikan persembuhan yang baik.

\section{- INFORMASI PENULIS}

Penulis untuk Korespondensi

*AP: mihardi.ap@gmail.com

Divisi Penyakit Dalam, Wing 2, Level 3

Departemen Klinik, Reproduksi dan Patologi,

Fakultas Kedokteran Hewan, Institut Pertanian Bogor, Bogor

Jl. Agatis, Kampus IPB Dramaga Bogor 16680

\section{- PUSTAKA ACUAN}

Bartges JW, Kirk CA. 2006. Nutrition and lower urinary tract disease in cats. Vet Clin North Am: Small AnimPract3: 1361-76.

Brown SA. 2018. Urolithiasis in small animals. [tehubung bekala]. https://www.msdvetmanual.com/urinary-system/noninfectiousdiseases-of-the-urinary-system-in-small-animals/urolithiasis-insmall-animals. [1 Februari 2019].

Gerber B, Boretti FS, Kley S, Laluha P, Muller C, Sieber N, Untere S, Wenger M, Fluckiger M, Glaus T, Reusch CE. 2005. Evaluation of clinical signs and causes of lower urinary tract disease in Europian cats. J. Small. Anim. Pract. 46: 571-577.

Grauer GF. 2015. Feline struvite and calcium oxalate urolithiasis. Today's. Vet. Pract. 5(5): 14-20.

Hesse A, Heiger R. 2009. A Colour Handbook of Urinary Stones in Small Animal Medicine. Manson Publishing: Germany.

Kojrys SL, Skupien EM, Snarska A, Krystkiewicz W, Pomianowski A. 2017. Evaluation of clinical signs and causes of lower urinary tract disease in polish cats. Vet. Med. 62 (7):386393.

Mihardi AP, Paramita IM, Pakpahan SN, Widodo S. 2018. Identifikasi klinis klistaluria pada kasus Feline Lower Urinary Track Disease (FLUTD) di klinik hewan Maximus Pet Care. Proceedings of the 20th FAVA \& the 15th KIVNAS PDHI 2018. Bali (ID): Nusa Dua Bali. 308-310.

Osborne CA, Lulich JP, Kruger JM, Ulrich LK, Koehler LA. 2009. Analysis of 451,891 canine uroliths, feline uroliths, and feline uretral plugs from 1981 to 2007: perspectives from the Minnesota Urolith Center. Vet. Clin. Small. Anim. 39:183-197.

Tion MT, Dvorska J, Saganuwan SA. 2015. A review on urolithiasis in dogs and cats. BJVM. 18 (1): 1-18.

Ulrich LK, Bird KA, Koehler LA, Swanson L. 1996. Urolith analysis, submission, methods and interpretation. Vet. Clin. Nort. Am: Small. Anim. Pract. 26: 393-400. 